\title{
Selective Alterations in Gene Expression for NMDA Receptor Subunits in Prefrontal Cortex of Schizophrenics
}

\author{
S. Akbarian, ${ }^{1}$ N. J. Sucher, ${ }^{3}$ D. Bradley, ${ }^{1}$ A. Tafazzoli, ${ }^{1}$ D. Trinh, ${ }^{1}$ W. P. Hetrick, ${ }^{2}$ S. G. Potkin, ${ }^{2}$ \\ C. A. Sandman, ${ }^{2}$ W. E. Bunney, Jr., ${ }^{2}$ and E. G. Jones ${ }^{1}$ \\ ${ }^{1}$ Department of Anatomy and Neurobiology and ${ }^{2}$ Department of Psychiatry and Human Behavior, University of California, \\ Irvine, California 92717, and 'Department of Neurology, Children's Hospital, Harvard Medical School, Boston, \\ Massachusetts 02115
}

NMDA receptor antagonists can induce a schizophrenia-like psychosis, but the role of NMDA receptors in the pathophysiology of schizophrenia remains unclear. Expression patterns of mRNAs for five NMDA receptor subunits (NR1/NR2A-D) were determined by in situ hybridization in prefrontal, parieto-temporal, and cerebellar cortex of brains from schizophrenics and from neuroleptic-treated and nonmedicated controls.

In the cerebral cortex of both schizophrenics and controls, mRNAs for NR1, NR2A, NR2B, and NR2D subunits were preferentially expressed in layers II/III, $\mathrm{Va}$, and $\mathrm{Vla}$, with much higher levels in the prefrontal than in the parieto-temporal cortex. Levels of mRNA for the NR2C subunit were very low overall. By contrast, the cerebellar cortex of both schizophrenics and controls contained very high levels of NR2C subunit mRNA, whereas levels for the other subunit mRNAs were very low, except NR1, for which levels were moderate. Significant alterations in the schizophrenic cohort were confined to the prefrontal cortex. Here there was a shift in the relative proportions of mRNAs for the NR2 subunit family, with a 53\% relative increase in expression of the NR2D subunit mRNA. No comparable changes were found in neuroleptic-treated or untreated controls.

These findings indicate regional heterogeneity of NMDA receptor subunit expression in human cerebral and cerebellar cortex. In schizophrenics, the alterations in expression of NR2 subunit mRNA in prefrontal cortex are potential indicators of deficits in NMDA receptor-mediated neurotransmission accompanying functional hypoactivity of the frontal lobes.

Key words: glutamate; excitatory amino acid receptors; human association cortex; frontal lobe; temporal lobe; cerebellum
The NMDA receptor channel blockers, ketamine and phencyclidine, in normal human subjects can induce psychosis that includes many symptoms and cognitive disturbances commonly observed in patients with schizophrenia (Javitt and Zukin, 1991; Krystal et al., 1994). Disturbances of NMDA receptor-mediated neurotransmission may therefore be involved in the pathophysiology of schizophrenia (Olney, 1989; Carlsson and Carlsson, 1990; Bunney et al., 1995). In schizophrenics, NMDA receptor antagonists produce long-lasting exacerbations of psychotic symptoms (Luby et al., 1959), whereas treatment with glycine, an obligatory facilitator of NMDA receptors (Johnson and Ascher, 1987), can lead to improvement of symptoms, at least in some patients (Rosse et al., 1989; Potkin et al., 1990; Javitt et al., 1994).

Currently, evidence for a defect of NMDA receptor function in schizophrcnia remains inconclusive. Receptor binding studies report inconsistent abnormalities in NMDA receptor distribution in prefrontal or medial temporal cortex of schizophrenic brains (Kornhuber et al., 1989; Kerwin et al., 1990; Simpson et al., 1991;

Received June 28, 1995; revised Sept. 6, 1995; accepted Sept. 13, 1995.

This work was supported by Grant MH44188 from the National Institute of Mental Health, United States Public Health Service, by the National Alliance for Research on Schizophrenia and Depression, and by a Stanley Award from the National Alliance for the Mentally IIl. We thank Dr. W. W. Tourtellotte and Ms. I. Rosario at the National Neurological Research Specimen Bank, Los Angeles, CA, for providing resources for storage and processing of brains, Mr. Clyde King for technical assistance, Mr. J. Beisner and the staff of the Orange County Sheriff/ Coroner's office, and Dr. W. Lowell at the Ventura County Medical Examiner/ Coroner's office.

Correspondence should be addressed to Dr. Edward G. Jones, Department of Anatomy and Neurobiology, University of California, Irvine, CA 92717.

Copyright (C) 1995 Society for Neuroscience $0270-6474 / 95 / 160019-12 \$ 05.00 / 0$
Ulas and Cotman, 1993; Ishimaru et al., 1994). Increased binding has been reported in the putamen of schizophrenics, but it may be caused by neuroleptic medication (Kornhuber et al., 1989; Fitzgerald et al., 1995).

The recent cloning of several NMDA receptor subunits (Kutsuwada et al., 1992; Monyer et al., 1992) makes it possible to study potential disturbances of NMDA-receptors in the schizophrenic brain at the molccular level. Native NMDA receptors consist of heteromeric assemblies of subunits (Kumar et al., 1991). Five NMDA receptor subunits (NR1/NR2A-D) have been identified in mammalian brain (Hollmann and Heinemann, 1994). Native NMDA receptors are thought to be composed of an NR1 subunit together with different NR2 subunits; these show differential binding affinities for agonists and antagonists and differences in conductance properties, in sensitivity to sulfhydryl redox agents, and in threshold of voltage-dependent $\mathrm{Mg}^{2+}$ blockade (Kutsuwada et al., 1992; Monyer et al., 1994; Ishii ct al., 1993; Kohr ct al., 1994; Le Bourdelles et al., 1994; Sullivan et al., 1994). Expression of different combinations of receptor subunits in vivo indicates that the functional properties of NMDA receptors are regulated in part by differential gene expression for individual subunits (Buller et al., 1994; Farrant et al., 1994; Fitzgerald et al., 1995).

Any changes in gene expression for NMDA receptor subunits in brains of schizophrenics may indicate abnormalities in the molecular composition and biophysical properties of NMDA receptors. However, with the exception of the NR1 subunit (Bockers ct al., 1994), there have been no studies of the pattern of gene expression for NMDA receptor subunit polypeptides in human brain, and nothing is known about potential alterations in schizophrenia. 
Table 1. Demographic variables of schizophrenics and controls

\begin{tabular}{|c|c|c|c|c|c|}
\hline Diagnosis & $\mathrm{N}$ & $\begin{array}{l}\text { Age } \pm \\
\text { SEM }(y)\end{array}$ & Gender & $\begin{array}{l}\operatorname{AT}^{a} \pm \\
\text { SEM (hr) }\end{array}$ & $\begin{array}{l}\text { FST }^{b} \pm \\
\text { SEM }(y)\end{array}$ \\
\hline Schizophrenia & 15 & $55.2 \pm 5.4$ & $3 \mathrm{~F} / 12 \mathrm{M}$ & $16.1 \pm 2.2$ & $2.6 \pm 0.3$ \\
\hline Controls & 15 & $57.4+5.3$ & $3 \mathrm{~F} / 12 \mathrm{M}$ & $15.1+2.0$ & $3.2+0.3$ \\
\hline $\begin{array}{l}\text { Neuroleptic-treated } \\
\text { controls }\end{array}$ & 8 & $52.4 \pm 8.2$ & $3 \mathrm{~F} / 5 \mathrm{M}$ & $16.5 \pm 4.4$ & $2.4 \pm 0.5$ \\
\hline
\end{tabular}

"Autolysis time.

${ }^{b}$ Freezer storage time.

Postmortem brains of schizophrenics and controls were used in the present study to analyze expression of all five NMDA receptor subunit mRNAs and the relative proportions of the mRNAs for the four NR2 subunit polypeptides in prefrontal cortex, a neocortical region thought to be primarily involved in the pathophysiology of schizophrenia ( $\mathrm{Kec}$ and Weinberger, 1986). 'The findings were compared with data obtained from parieto-temporal cortex and cercbcllar cortex of the samc brains.

\section{MATERIALS AND METHODS}

Three groups of brains were included in this study. The first group consisted of brains from 15 schizophrenics (Table 1), the second group consisted of brains from 15 controls who had had no neurological or psychiatric illness, and the third group consisted of brains from eight cases with three different neurological and psychiatric disorders, united by their previous exposure to neuroleptics (bipolar affective disorder, five cases; bipolar affective disorder and psychoactive substance abuse, one case; and Alzheimer's disease, two cases). This group was included to determine whether changes observed in the schizophrenic cohort could be attributable to neuroleptic treatment. The term "controls" will be used for the second group, and the term "neuroleptic-treated controls" will be used for the third group. A medical history before death was available for every case. Brain tissue was obtained from a brain bank in the Department of Anatomy and Neurobiology at the University of California, Irvine. Diagnosis of schizophrenia and of other psychiatric disorders was made pre- and postmortem by using DSM IV criteria. Clinical diagnosis suggestive of Alzheimer's disease in two cases of the neuroleptic-treated cohort was confirmed by detailed neuropathological examination according to CERAD criteria. All schizophrenics had a chronic, nonremitting pattern of illness. Schizophrenics with other psychiatric or neurological disorders, including substance abuse, were excluded. The three groups of brains had only minimal and nonsignificant differences with regard to age, autolysis time (time between death and freezing of the brains), and storage period of the frozen brains (Table 1).

Neuroleptic drugs taken by 14 of the 15 schizophrenics and the 8 neuroleptic-treated controls at the time of death were butyrophenones, phenothiazines, and thioxanthenes. Atypical neuroleptics such as benzamides (e.g., Sulpiride) or dibenzazepines (e.g., Clozapine) had not been taken by any of the cases. The remaining schizophrenic had received no neuroleptics in the 10 years before death.

Procedures for removal and storage of the brains have been described previously (Jones et al., 1992). From the left side of each schizophrenic and normal control brain, blocks were cut from the following regions: (1) the pole of the frontal lobe corresponding to Brodmann's area 10 (Brodmann, 1909; Preuss and Goldman-Rakic, 1991); (2) the angular gyrus at the junction of the parietal and temporal lobes corresponding to Brodmann's area 39 (Brodmann, 1909); and (3) the cerebellar cortex located in the dorsolateral portion of the cerebellar hemisphere (lateral to vermal lobules I to V). From each brain of the neuroleptic-treated cohort, blocks were cut only from the frontal lobe (area 10).

All blocks were brought from $-75^{\circ} \mathrm{C}$ up to $4^{\circ} \mathrm{C}$ over a period of $20 \mathrm{~min}$. They were then fixed by immersion in $4 \%$ paraformaldehyde in $0.1 \mathrm{M}$

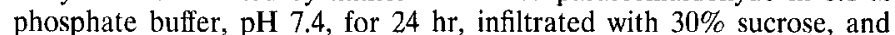
refrozen in dry ice. None of the brains showed freezing artifacts at the level of light microscopy, which is in accord with previous studies on frozen specimens derived from the same brain bank.

Blocks of cerebral cortex were cut in six series of $60-\mu \mathrm{m}$-thick sections and onc scries of $30-\mu \mathrm{m}$-thick scctions on a freezing microtome. One series of $60-\mu \mathrm{m}$-thick sections was stained with thionin, and the remain- der were stored in sterile $4 \%$ paraformaldehyde at $4^{\circ} \mathrm{C}$ for $72 \mathrm{hr}$, then processed frec-floating for in situ hybridization histochemistry. The 30$\mu \mathrm{m}$-thick sections were used for thioflavin-S staining. Except for the two Alzheimer's cases, none of the brains showed evidence of a chronic neurodegenerative process.

Blocks of cerebellar cortex were cut in six series of $50-\mu \mathrm{m}$-thick sections on a freezing microtome, stored in sterile $4 \%$ paraformaldehyde at $4^{\circ} \mathrm{C}$ for $8 \mathrm{hr}$, then mounted on Vectabond (Vector)-coated slides, air-dried for a period of $24 \mathrm{hr}$, then defatted by incubation in chloroform/ ethanol (1:1) for $24 \mathrm{hr}$, rehydrated in descending alcohols, then air-dried again for $6 \mathrm{hr}$ and stored at $-75^{\circ} \mathrm{C}$ until further processing as slidemounted sections for in situ hybridization histochemistry. Adjacent sections were stained with thionin. The slide-mounted procedure was necessary because the very fine folial pattern of the cerebellar cortex made this tissue unsuitable for the free-floating procedure.

In situ hybridization histochemistry. The following cDNA templates of NMDA-receptor subunits were used for the construction of ${ }^{33} \mathrm{P}$-labeled cRNA probes with similar $\mathrm{G} / \mathrm{C}$ ratios and a similar specific activity of $\sim 1.6 \times 10^{9} \mathrm{cpm} / \mu \mathrm{g}$. No cross-hybridization of the probes was observed when used in Northern blot or RNase protection assays with rat brain total RNA (N. J. Sucher, unpublished observations).

(1) A 2700 bp cDNA clone fully complementary to the mRNA of splice variant $C$ of the NR1 subunit and $93-100 \%$ complementary to the entire cDNA length of the other splice variants of the NR1 subunit (Sugihara et al., 1992), cloned into the SmaI restriction site of the pBKS(+) Bluescript vector, was linearized with $X b a I$ for the construction of antisense cRNA probes and with HindIII for the construction of sense cRNA probes.

(2) A 566 bp segment, corresponding to bases 1585-2154 of rat NR2A cDNA (GenBank accession number M91561), cloned into the SmaI restriction site of the $\mathrm{pBKS}(+)$ Bluescript vector, was linearized with $B a m \mathrm{HI}$ for the construction of antisense cRNA probes and with EcoRI for the construction of sense cRNA probes.

(3) A 569 bp segment, corresponding to bases 1423-1992 of rat NR2B cDNA (GenBank accession number M91562), cloned into the SmaI restriction site of the $\mathrm{pBKS}(+)$ Bluescript vector, was linearized with $B a m \mathrm{HI}$ for the construction of antisense cRNA probes and with EcoRI for the construction of sense cRNA probes.

(4) A 295 bp segment, corresponding to bases $1525-1820$ of rat NR2C cDNA (GenBank accession number M91563), cloned into the EcoRI/ $K p n I$ restriction site of the pBKS( - ) Bluescript vector, was linearized with EcoRI for the construction of antisense cRNA probes and with KpnI for the construction of sense cRNA probes.

(5) A 592 bp segment, corresponding to bases 1471-2063 of rat NR2D cDNA (GenBank accession number D913213), cloned into the SmaI site of the pBKS(+) vector, was linearized with $B a m H I$ for the construction of antisense and with EcoRI for the construction of sense cRNA probes.

For in situ hybridization histochemistry, all solutions were prepared under sterile conditions. Free-floating sections (five/brain/area/riboprobe) were washed twice in $0.1 \mathrm{M}$ glycine $/ 0.1 \mathrm{M}$ phosphate buffer $(3 \mathrm{~min}$ each), then washed in $0.1 \mathrm{M}$ phosphate buffer $(15 \mathrm{~min})$ followed by treatment with proteinase $\mathrm{K}\left(2 \mu \mathrm{g} / \mathrm{ml}, \mathrm{pH} 8.0,37^{\circ} \mathrm{C}\right.$ for $\left.10 \mathrm{~min}\right)$, then incubated in $0.25 \%$ acetic anhydride $/ 0.1 \mathrm{M}$ triethanolamine $(10 \mathrm{~min})$, and washed twice in $2 \times \mathrm{SSC}$ (containing sodium thiosulfate, $0.16 \mathrm{gm} / 100 \mathrm{ml}$ ) for $15 \mathrm{~min}$ each. Sections were then incubated for $60 \mathrm{~min}$ at $60^{\circ} \mathrm{C}$ in the hybridization solution, which contained $50 \%$ deionized formamide, $10 \%$ dextran sulfate, $0.7 \%$ Ficoll, $0.7 \%$ polyvinyl pyrolidone, $10 \mathrm{mg} / \mathrm{ml}$ bovine serum albumin, $0.35 \mathrm{mg} / \mathrm{ml}$ denaturated herring sperm, $0.25 \mathrm{mg} / \mathrm{ml}$ yeast tRNA, and $40 \mathrm{~mm} / \mathrm{ml}$ dithiothreitol. After this preincubation step, sections were transferred to fresh hybridization solution containing $1.5 \times 10^{6}$ $\mathrm{cpm} / \mu \mathrm{l}$ of the ${ }^{33} \mathrm{P}$ sense or antisense riboprobe for $48 \mathrm{hr}$ at $60^{\circ} \mathrm{C}$. After hybridization, sections were washed twice in $4 \times \mathrm{SSC}$ at $60^{\circ} \mathrm{C}$ for $15 \mathrm{~min}$ each, treated with $20 \mu \mathrm{g} / \mathrm{ml}$ ribonuclease $\mathrm{A}\left(\mathrm{pH} 8.0\right.$ for $30 \mathrm{~min}$ at $45^{\circ} \mathrm{C}$ ), washed twice in $2 \times \mathrm{SSC}$ (each for $30 \mathrm{~min}$ at room temperature), twice in $0.5 \times \operatorname{SSC}\left(30 \mathrm{~min}\right.$ at $60^{\circ} \mathrm{C}$ each $)$, and twice in $0.1 \times \mathrm{SSC}\left(30 \mathrm{~min}\right.$ at $60^{\circ} \mathrm{C}$ each). After a final wash in $0.1 \times \mathrm{SSC}$ ( $30 \mathrm{~min}$ at room temperature), sections were mounted from $0.1 \mathrm{M}$ phosphate buffer on gelatin-coated slides, exposed on Amersham $\beta$ max film for 6 (NR1) or 9 (NR2A-D) $d$ at $4^{\circ} \mathrm{C}$. After development of the film, sections were counterstained with thionin, dehydrated through ascending alcohols, and coverslipped with DPX. The in situ hybridization protocol for the slide-mounted cerebellar sections was similar to that described above, except that the incubation time for the treatment with proteinase $K$ was 30 min instead of $10 \mathrm{~min}$ and preincubation in hybridization buffer was omitted. Instead, the sections were air-dried for $1 \mathrm{hr}$ after the last $2 \times \mathrm{SSC}$ wash, before being exposed for $48 \mathrm{hr}$ to hybridization buffer containing radiolabeled cRNA 


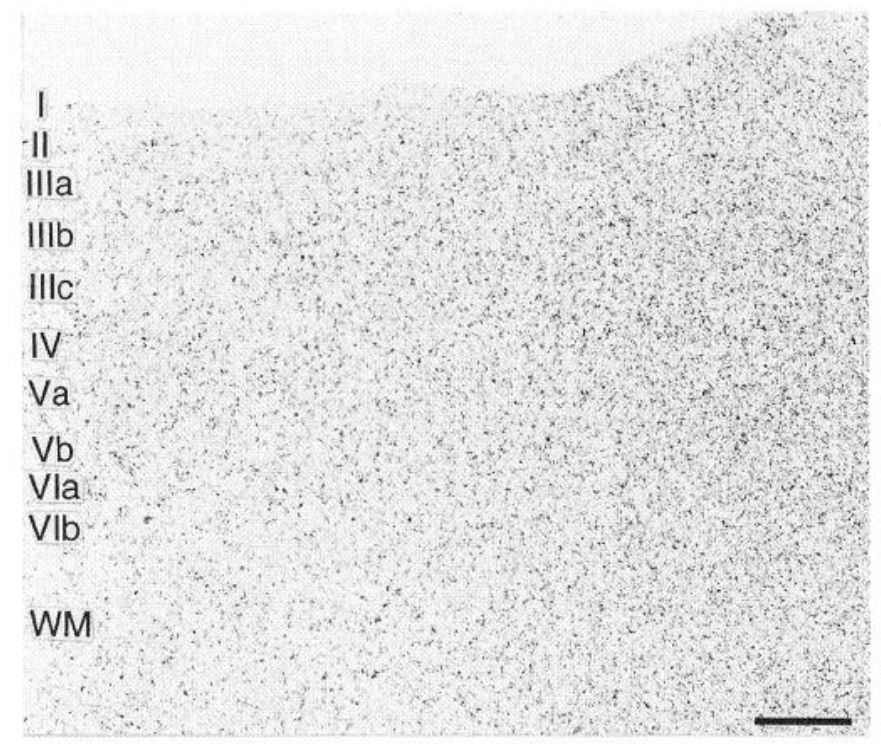

Figure 1. Photomicrograph of a film autoradiogram of a section from the prefrontal cortex of a control brain, hybridized with radiolabeled NR1 sense cRNA probe, showing typical pattern of background labeling found with sense probes for all subunit mRNAs. Note indistinguishable borders between gray and white matter. Scale bar, $500 \mu \mathrm{m}$.

probe. For all cerebellar sections, the exposure time on $\beta$ max film was $11 \mathrm{~d}$.

Hybridization with radiolabeled sense riboprobes resulted in very weak background labeling over the cerebral and cerebellar cortex and subcortical white matter, with indistinguishable borders between gray matter and white matter (Fig. 1).

Determination of $m R N A$ levels. Film autoradiograms of sections hybridized with ${ }^{33} \mathrm{P}$-labeled antisense cRNA probes were quantified under blind conditions by densitometry, using a microcomputer imaging device (MCID/M4, Imaging Research, St. Catherine's, Ontario). For the prefrontal and the parieto-temporal cortex, optical density readings were taken in 300- $\mu \mathrm{m}$-wide vertical strips across the full thickness of the cortex, and optical densities were determined separately for the thickness of each cortical layer by matching the autoradiogram readings to digitized images of the adjacent Nissl-stained section. Density readings in layers III, V, and VI included all sublayers (IIIa-c; Va,b; VIa,b). Optical density over white matter $>3 \mathrm{~mm}$ deep to overlying cortex was determined, and this value was used for background subtraction. From the five sections of each brain, anatomical region, and subunit, 10 measurements were taken. Absolute values of radioactivity in nanocuries per gram were determined from ${ }^{14} \mathrm{C}$ plastic standards (Amersham) exposed on the same sheet of film.

In the cerebellar cortex, optical densities were taken over the granule cell layer in a rectangular frame $(300 \times 200 \mu \mathrm{m}$ wide $)$ and the density taken over cerebellar white matter $>1 \mathrm{~mm}$ distant from overlying cortex was used for background subtraction.

Statistical analysis. For each brain, anatomical region, and subunit, the mean value of the 10 measurements was calculated. In the prefrontal and parieto-temporal cortex, the mean values for each of the six cortical layers were calculated separately, in addition to the arithmetic mean of the six cortical layers together. The relative proportions of the four NR2 subunit mRNA were determined for each case and each anatomical region (prefrontal cortex, parieto-temporal cortex, cerebellar cortex) separately by using the value of a particular NR2 subunit as the numerator and the sum of all four subunits (NR2A-D) as the denominator. For each cohort, the mean and SEM was calculated as the mean of the individual mean values.

Significance of differences in mRNA levels between the schizophrenic and control cohorts was tested for each anatomical region separately by using multivariate analysis of variance (MANOVA) with repeated measures and by using the cohorts as groups and the mean values of the five subunits, averaged across layers, as variates. In addition, ANOVA was conducted for each subunit separately.

For each anatomical region, significance of differences in the propor- tions of NR2 subunit mRNAs was determined between cohorts by using MANOVA with two cohorts as groups and the proportions of the four NR2 subunits as variates, and ANOVA was conducted to determine significance of differences for each NR2 subunit separately. The MANOVAs and ANOVAs were performed with BMDP software (BMDP Statistical Software, Los Angeles, CA), using a procedure described by Tatsuoka (1988).

\section{RESULTS}

\section{Laminar expression of NMDA receptor subunit mRNA in the prefrontal and parieto-temporal cortex} Hybridization with the NR1 probe

In control brains, hybridization with antisense riboprobes for NR1 subunit mRNA resulted in significant labeling of all six cortical layers (Fig. $2 B$ ). In the prefrontal cortex, labeling was heavy in layers II, IIIa-c, Va, and VIa. Labeling in layers IV, Vb, and VIb was less pronounced. Layer I showed the weakest hybridization. In the parieto-temporal cortex, labeling was most pronounced in layers II, IIIa, IIIc, Va, and VIa, with intermediate labeling in layers IIIb, IV, and Vb, and lowest levels in layers I and VIb (Fig. $3 B$ ). Sections from the schizophrenic and neuroleptic-treated control brains showed a laminar pattern of hybridization similar to that described for the controls.

\section{Hybridization with the NR2 probes}

In control brains, sections hybridized with antisense riboprobes for NR2A, NR2B, and NR2D subunit mRNAs resulted in significant labeling of all cortical layers. Labeling of sections hybridized with NR2A and NR2B subunit cRNA probes was more intense (Fig. 2C,D), compared with the labeling of sections hybridized with NR2D subunit cRNA probes (Fig. $2 F$ ). The laminar expression pattern of the NR2A and NR2B subunit mRNAs was similar to that seen in sections hybridized with NR1 probes. In the prefrontal cortex, labeling was pronounced in layers II, IIIa-c, Va, and $\mathrm{VIa}$, with intermediate labeling in layers $\mathrm{IV}, \mathrm{Vb}$, and $\mathrm{VIb}$, and lowest labeling in layer I (Fig. 2C,D). In the parieto-temporal cortex, labeling was most pronounced in layers II, IIIa-c, IV, Va, and VIa, compared with layers $\mathrm{I}, \mathrm{Vb}$, and VIb (Fig. $3 C, D$ ). The expression of NR2D subunit mRNA in the prefrontal and parietotemporal cortex was more pronounced in layers II, IIIa-c, IV, Va, and VIa, compared with layers I, Vb, and VIb (Figs. $2 F, 3 F$ ). Sections of control brains that were hybridized with antisense riboprobes for NR2C subunit mRNA showed very weak labeling over layers II-VI of the prefrontal and parieto-temporal cortex, but no further differentiation of the laminar expression pattern was detected (Figs. $2 E, 3 E$ ). The faint signals on autoradiograms of the relevant sections compared with controls indicated that levels of expression for this subunit were close to the lower limit of the detectability of specific mRNA expression.

Sections of schizophrenic and neuroleptic-treated control brains hybridized with the NR2 probes showed the same laminar expression pattern as described for the controls.

\section{Expression of NMDA receptor subunits in the cerebellar cortex}

\section{Hybridization with the NRI probe}

Sections from control brains hybridized with NR1 antisense cRNA probes resulted in very intense labeling in the Purkinje cell layer, with additional strong labeling in the granule cell layer of the cerebellar cortex. In the Purkinje cell layer, clusters of intense hybridization signal were visible over the row of Purkinje cells as seen in adjacent Nissl-stained sections (Fig. 4A,B). Labeling intensity in the molecular layer was low and similar in intensity to 

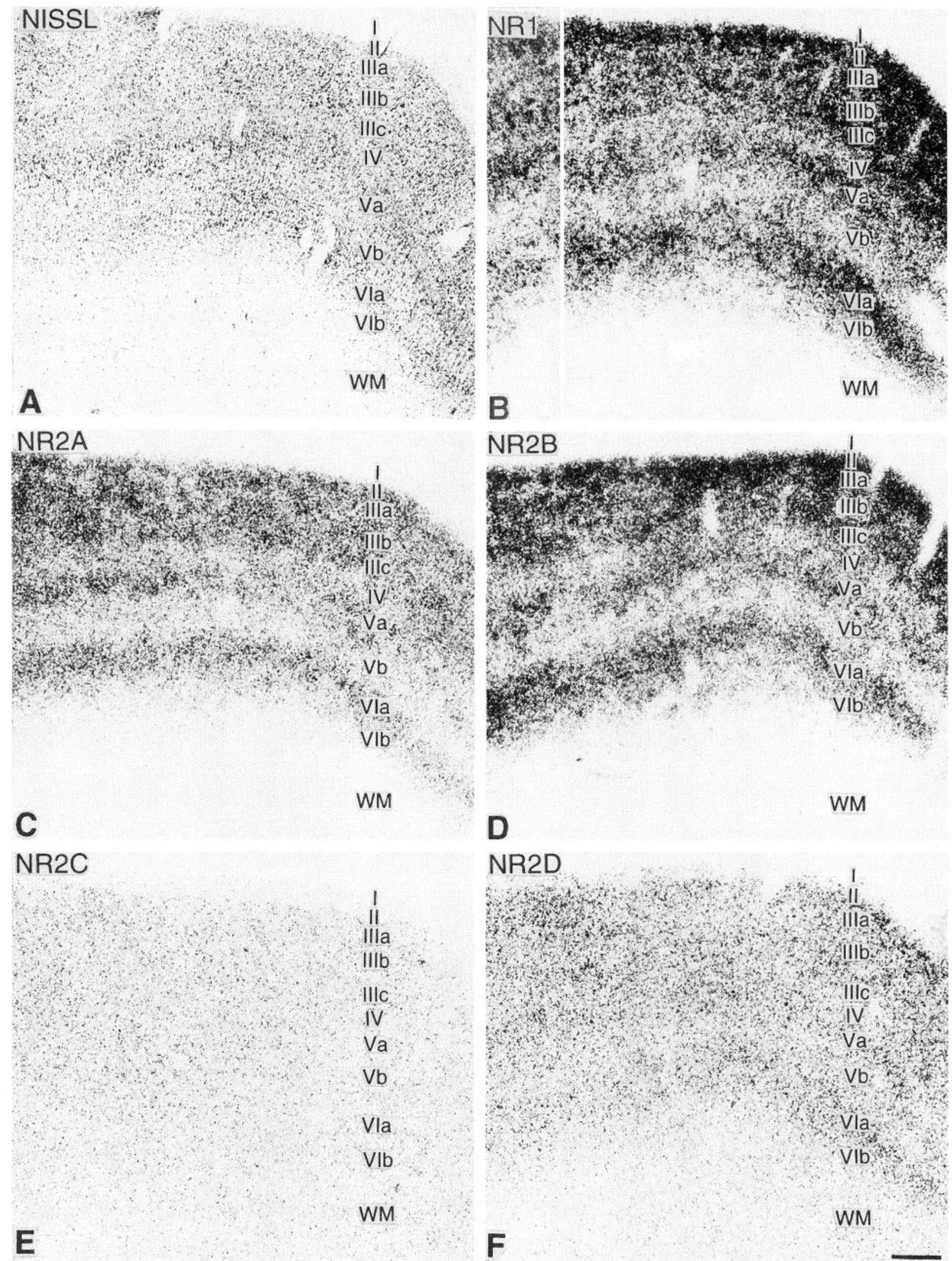

Figure 2. Photomicrographs of a thionin-stained section $(A)$ from the prefrontal cortex (Brodmann's area 10$)$ and of film autoradiograms $(B-F)$ of adjacent sections hybridized with NR1, NR2A, NR2B, NR2C, and NR2D subunit-specific cRNA probes as indicated $(B-F)$, showing the laminar expression pattern of the subunit-specific mRNAs in layers I-VI of a control brain. Inset in $B$ is from a schizophrenic brain and shows the same laminar pattern of NR1 subunit expression. This is typical of all probes used. $W M$, white matter. Scale bar, $500 \mu \mathrm{m}$. 


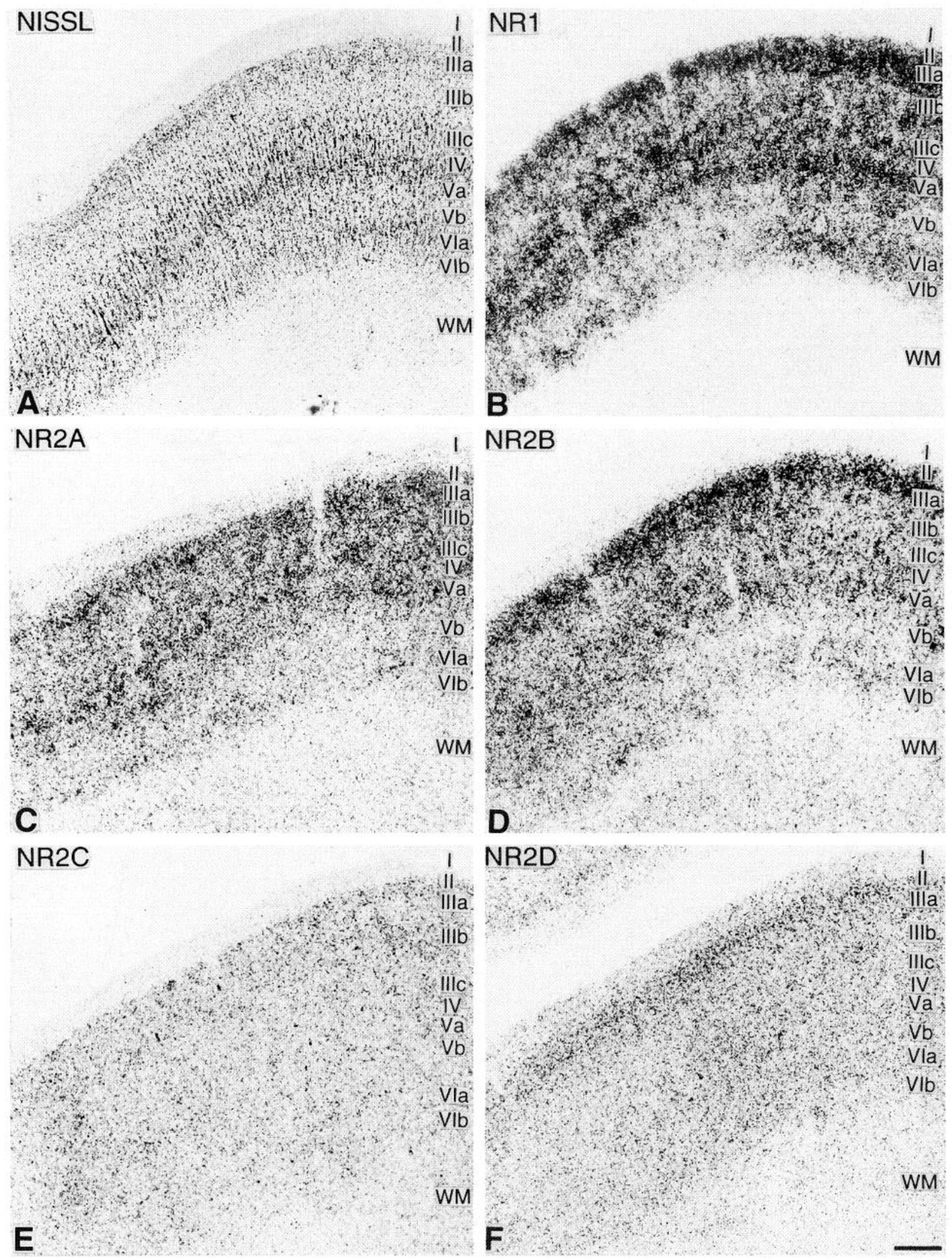

Figure 3. Photomicrographs of a thionin-stained section $(A)$ from the parieto-temporal cortex (Brodmann's area 39$)$ and of film autoradiograms $(B-F)$ of adjacent sections hybridized with NR1, NR2A, NR2B, NR2C, and NR2D subunit-specific cRNA probes as indicated (B-F), showing the laminar expression pattern of the subunit-specific mRNAs in layers I-VI of a control brain. $W M$, white matter. Scale bar, $500 \mu \mathrm{m}$. 

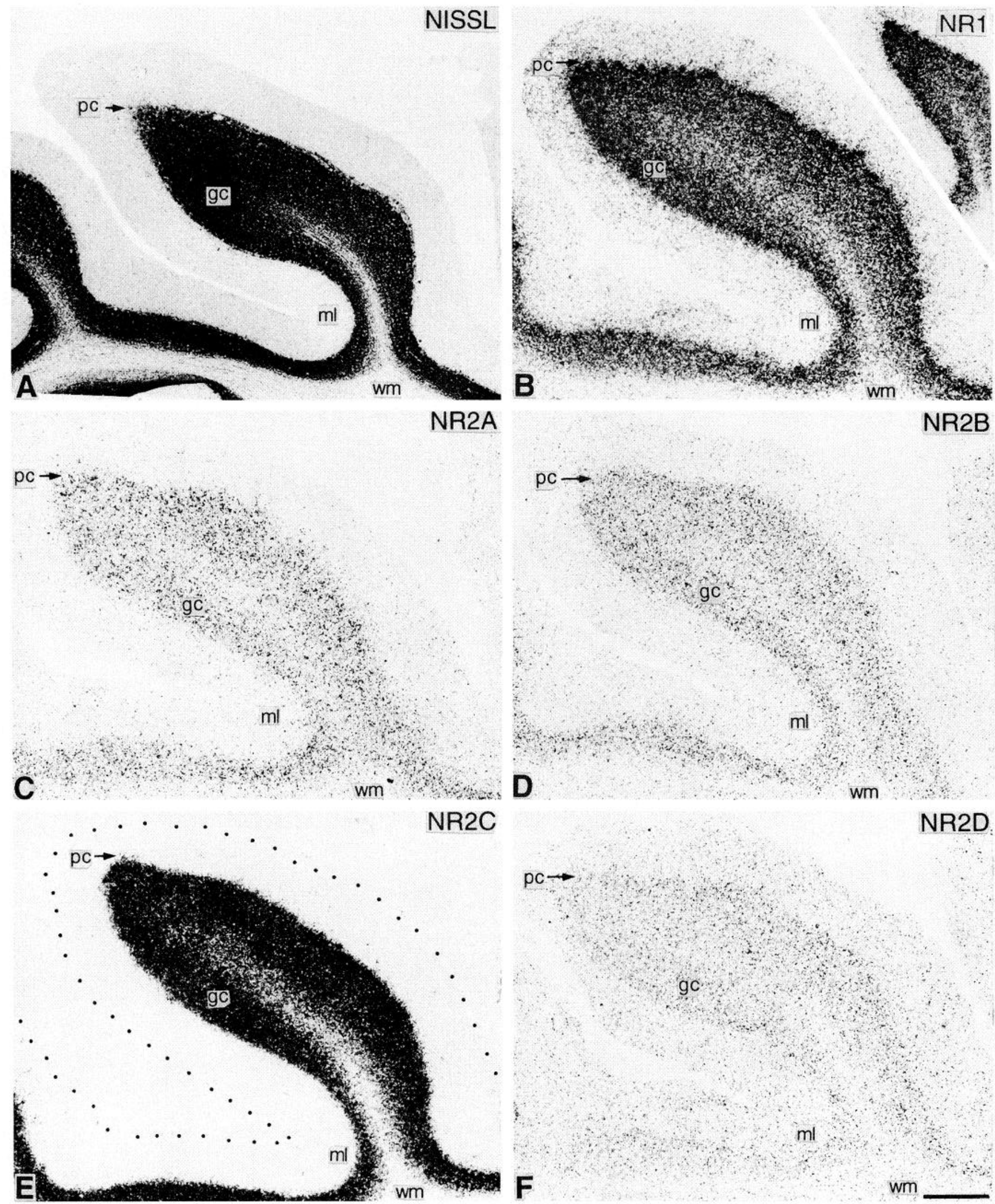

Figure 4. Photomicrographs of a thionin-stained section $(A)$ from the cerebellar cortex and of film autoradiograms $(B-F)$ of adjacent sections hybridized with NR1, NR2A, NR2B, NR2C, and NR2D subunit-specific cRNA probes as indicated $(B-F)$, showing the laminar expression pattern of the subunit-specific mRNA in the brain of a schizophrenic. Inset in $B$ shows identical pattern of NR1 subunit expression in a control brain, which is typical of all probes used. Dotted line in $E$ indicates surface of the cerebellum. $g c$, granule cell layer; $m l$, molecular layer; $p c$, Purkinje cell layer; $w m$, white matter. Scale bar, $500 \mu \mathrm{m}$. 

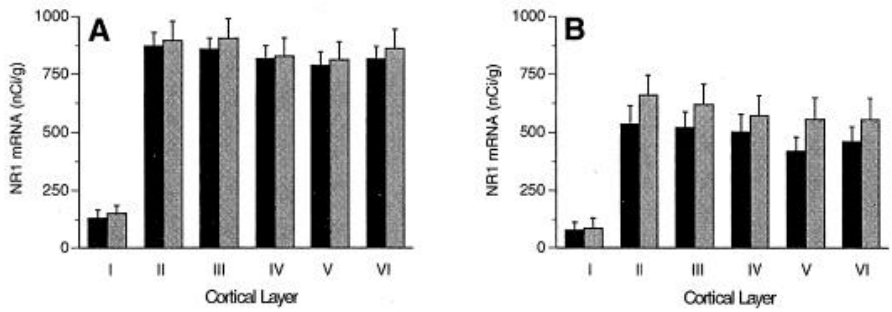

Figure 5. Levels of NR1 subunit-specific mRNA expression, as indicated on the abscissae, across the six cortical layers (ordinates) in the prefrontal $(A)$ and parieto-temporal $(B)$ cortex. Data are shown as cohort mean \pm SEM. Black bars, schizophrenics; shadowed bars, (unmedicated) controls. Differences within layers are not statistically significant.

the labeling of the white matter. Sections from the schizophrenic brains showed a laminar pattern of hybridization similar to that described for the controls.

\section{Hybridization with the NR2 probes}

Sections from cerebella of control brains hybridized with NR2C cRNA probes showed very intense labeling in the granule cell layer, whereas labeling in the Purkinje cell layer and in the molecular layer was very low and similar in intensity to the background labeling in the white matter (Fig. $4 E$ ). Sections from control brains hybridized with NR2A, NR2B, and NR2D cRNA probes showed very weak labeling in the granule cell layer (Fig. $4 C, D, F)$. Labeling intensity in the molecular layer and in the Purkinje cell layer was weakest and similar in intensity to the background labeling of the white matter. Sections from cerebella of schizophrenic brains showed a laminar pattern of hybridization and differential intensity of labeling for the individual NR2 subunit mRNA similar to that described for the controls.

\section{Quantitative analysis of NMDA receptor subunit mRNA levels in the prefrontal and parieto-temporal cortex in schizophrenic and control brains}

\section{Levels of $m R N A$ in individual cortical layers}

NR1 subunit. In the prefrontal cortex of the control cohort, levels of mRNA for the NR1 subunit were $811-907 \mathrm{nCi} / \mathrm{gm}$ in layers II-VI and $151 \mathrm{nCi} / \mathrm{gm}$ in layer I (Fig. $5 A$ ). The differences compared with the schizophrenic cohort were $<5 \%$ in layers II-VI, but there was a $13 \%$ decrease in NR1 mRNA levels in layer I of schizophrenics. These differences did not reach the level of significance $(p=0.91)$. In neuroleptic-treated controls, there was an $18 \%$ increase in NR1 mRNA levels in layer I, together with a $8-23 \%$ decrease in layers II-VI, compared with controls. These differences did not reach the level of significance $(p=0.92)$.

In the parieto-temporal cortex of the control cohort, levels of mRNA for the NR1 subunit were $556-660 \mathrm{nCi} / \mathrm{gm}$ in layers II-VI and $87 \mathrm{nCi} / \mathrm{gm}$ in layer I (Fig. 5B). Schizophrenics showed a 11-20\% decrease in NR1 mRNA levels in layers I-VI, compared with normal controls (Fig. $5 B$ ). These differences were not significant $(p=0.40)$.

$N R 2 A$ subunit. In the prefrontal cortex of the control cohort, levels of mRNA for the NR2A subunit were $439-517 \mathrm{nCi} / \mathrm{gm}$ in layers II-VI and $37 \mathrm{nCi} / \mathrm{gm}$ in layer I (Fig: $6 \mathrm{~A}$ ). In the schizophrenic cohort there was a $10-16 \%$ decrease in layers II-VI and a $12 \%$ increase in layer $\mathrm{I}$, but these did not reach the level of significance $(p=0.31)$. In the neuroleptic-treated control cohort, there was a $10-15 \%$ decrease in layers II-VI compared with
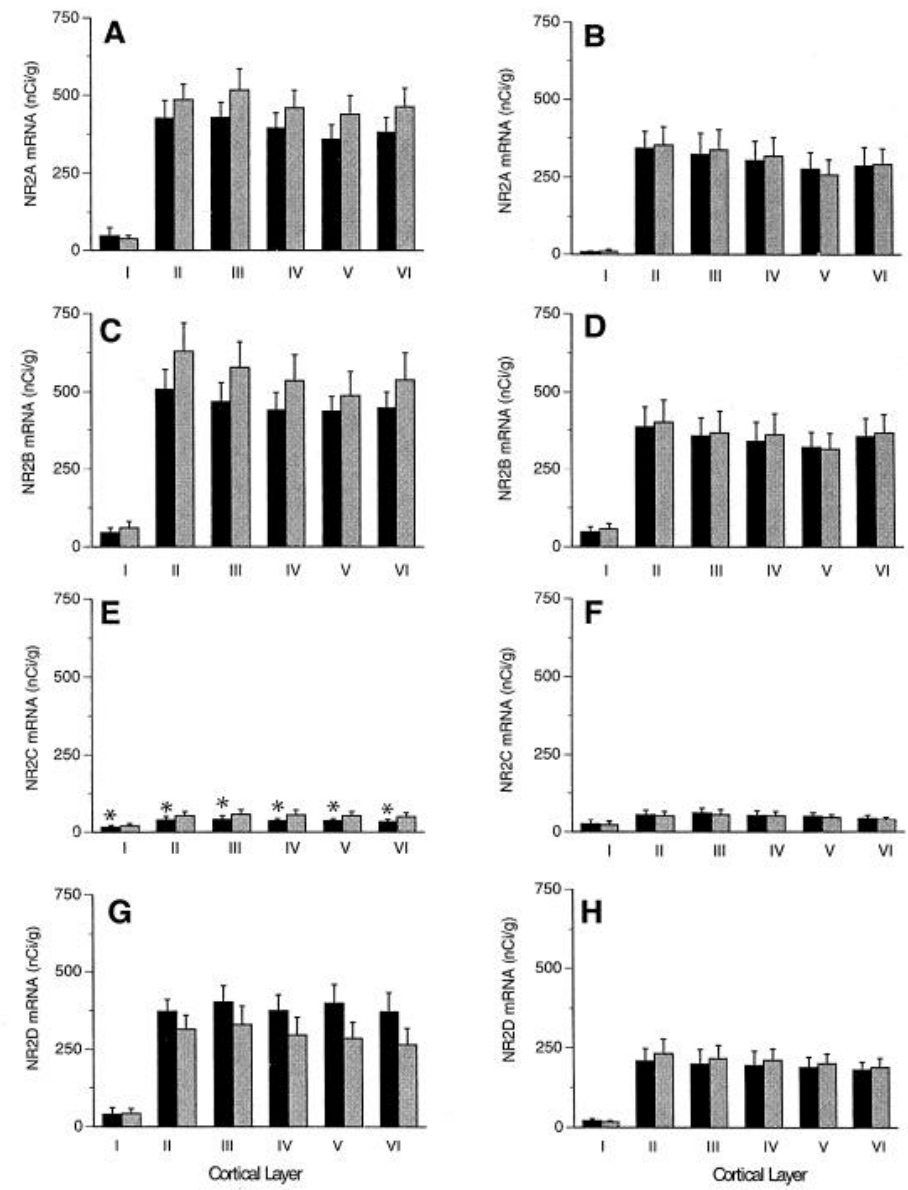

Figure 6. Levels of NR2 subunit-specific mRNA expression, as indicated on the abscissae, across the six cortical layers (ordinates) in the prefrontal $(A, C, E, G)$ and in the parieto-temporal $(B, D, F, H)$ cortex. Conventions are the same as in Figure 5. Differences within layers are not statistically significant except for NR2C (asterisks, $E$ ).

controls. These differences did not reach the level of significance $(p=0.72)$.

In the parieto-temporal cortex of the control cohort, levels of mRNA for the NR2A subunit were $258-353 \mathrm{nCi} / \mathrm{gm}$ in layers II-VI and $10 \mathrm{nCi} / \mathrm{gm}$ in layer I (Fig. $6 B$ ). The schizophrenic cohort showed a $3-8 \%$ decrease compared with controls. These differences were not significant $(p=0.89)$.

$N R 2 B$ subunit. In the prefrontal cortex of the control cohort, levels of mRNA for the NR2A subunit were $48-629 \mathrm{nCi} / \mathrm{gm}$ in layers II-VI and $60 \mathrm{nCi} / \mathrm{gm}$ in layer I (Fig. 6C). In the schizophrenic cohort, there was a $16-25 \%$ decrease in all layers, but this did not reach the level of significance $(p=0.36)$. In the neuroleptic-treated control cohort, there was a $10-25 \%$ decrease in layers I-VI compared with controls, but these differences did not reach the level of significance $(p=0.24)$.

In the parieto-temporal cortex of the control cohort, NR2B mRNA levels were $314-400 \mathrm{nCi} / \mathrm{gm}$ in layers II-VI and $56 \mathrm{nCi} / \mathrm{gm}$ in layer I (Fig. 6D). Schizophrenics showed a 3-10\% decrease in all layers, but these differences were not significant $(p=0.50)$.

$N R 2 C$ subunit. In the prefrontal cortex of controls, levels of mRNA for the NR2C subunit were $49-57 \mathrm{nCi} / \mathrm{gm}$ in layers II-VI and $22 \mathrm{nCi} / \mathrm{gm}$ in layer I (Fig. $6 E$ ). In the schizophrenic cohort, there was a $22-41 \%$ decrease in mRNA levels for NR2C subunit in layers I-VI. These differences were significant $(p=0.02)$. In 
Table 2. Comparison of overall mRNA levels in prefrontal and parieto-temporal cortex

\begin{tabular}{|c|c|c|c|c|c|c|}
\hline \multirow[b]{2}{*}{ Subunit } & \multicolumn{2}{|c|}{ PFC (area 10) } & \multicolumn{2}{|c|}{ PTC (area 39) } & \multicolumn{2}{|c|}{$\%$ increase in PFC } \\
\hline & Schizophrenics & Controls & Schizophrenics & Controls & Schizophrenics & Controls \\
\hline NR1 & $756 \pm 58$ & $766 \pm 62$ & $442 \pm 60$ & $524 \pm 75$ & $71 \%$ & $46 \%$ \\
\hline NR2A & $352 \pm 41$ & $417 \pm 45$ & $253 \pm 50$ & $261 \pm 49$ & $39 \%$ & $59 \%$ \\
\hline NR2B & $381 \pm 49$ & $461 \pm 71$ & $300 \pm 52$ & $310 \pm 58$ & $27 \%$ & $48 \%$ \\
\hline $\mathrm{NR} 2 \mathrm{C}$ & $32 \pm 5$ & $47 \pm 7$ & $45 \pm 6$ & $42 \pm 5$ & $-28 \%$ & $13 \%$ \\
\hline NR2D & $337 \pm 35$ & $255 \pm 40$ & $173 \pm 26$ & $188 \pm 32$ & $94 \%$ & $35 \%$ \\
\hline
\end{tabular}

PFC, prefrontal cortex; PTC, parieto-temporal cortex.

neuroleptic-treated controls, there was a $6-14 \%$ decrease in mRNA levels for NR2C subunit in layers I-VI compared with controls. These differences were not significant ( $p=0.97)$.

In the parieto-temporal cortex of controls, mRNA levels for $\mathrm{NR} 2 \mathrm{C}$ subunit were $38-55 \mathrm{nCi} / \mathrm{gm}$ in layers II-VI and $32 \mathrm{nCi} / \mathrm{gm}$ in layer I (Fig. $6 F$ ). In the schizophrenic cohort, there was a $10-21 \%$ increase in mRNA levels for NR2C subunit. These differences were not significant $(p=0.76)$.

NR2D subunit. In the prefrontal cortex of controls, levels of mRNA for the NR2D subunit were $265-330 \mathrm{nCi} / \mathrm{gm}$ in layers II-VI and $43 \mathrm{nCi} / \mathrm{gm}$ in layer I. In the schizophrenic cohort, there was a $7-28 \%$ increase in mRNA levels for NR2D subunit in layers II-IV and a $40 \%$ increase in layers V and VI, together with a $5 \%$ decrease in layer I (Fig. 6G). These differences between the two cohorts did not reach the level of significance $(p=0.15)$. The differences between the neuroleptic-treated, nonschizophrenic cohort and the control cohort were $<10 \%$ in layers I-VI and without significance $(p=0.75)$.

In the parieto-temporal cortex of controls, levels of mRNA for the NR2D subunit were $188-232 \mathrm{nCi} / \mathrm{gm}$ in layers II-VI and 17 $\mathrm{nCi} / \mathrm{gm}$ in layer I. In the schizophrenic cohort, there was a $3-10 \%$ decrease in levels of NR2D mRNA in layers II-VI, together with a $20 \%$ increase in layer I (Fig. $6 H$ ). These differences did not reach the level of significance $(p=0.78)$.

\section{Overall levels of mRNA in prefrontal and parieto- temporal cortex of schizophrenic and control brains}

Overall levels of mRNAs for the five NMDA receptor subunits did not show significant differences between the prefrontal cortex of the schizophrenic and the control cohort (MANOVA: F $(5,24)$ $=1.79, p=0.15$ ). Also, no significant differences were found for overall mRNA levels in the parieto-temporal cortex (MANOVA: $\mathrm{F}(5,24)=1.15, p=0.36)$. Overall mRNA levels in the prefrontal cortex of the neuroleptic-treated control cohort did not differ significantly from the control cohort (MANOVA: $F(5,18)=0.28$, $p=0.92$ ) or from the schizophrenic cohort (MANOVA: $\mathrm{F}(5,18)$ $=1.87, p=0.15$ ).

It is evident from Figures 5 and 6 that overall levels of mRNA for the NR1 subunit and for the NR2 subunits in the prefrontal cortex of schizophrenics and controls are higher than in the parieto-temporal cortex. This result is summarized in Table 2, which shows for each cohort the levels of mRNA averaged across the six cortical layers and the percentage increase in the prefrontal cortex compared with the parieto-temporal cortex. The differences between the two cortical regions were significant both in the schizophrenic and in the control cohort (schizophrenics, MANOVA: $F(5,24)=4.49, p=0.005$; controls, MANOVA: $\mathrm{F}(5,24)=2.81, p=0.03)$.
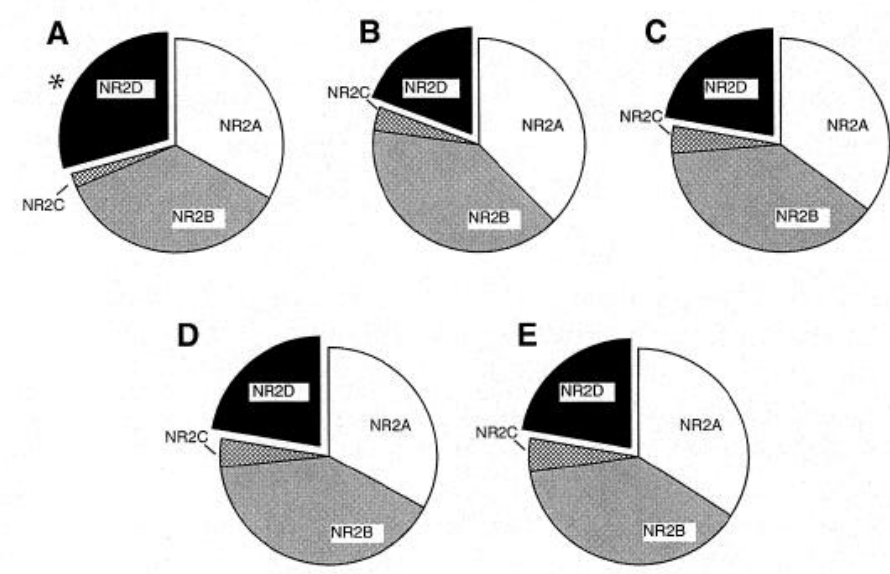

Figure 7. Pie charts of the relative proportions of NR2 subunit mRNAs in the prefrontal cortex of schizophrenics $(A)$, controls $(B)$, and neuroleptic-treated controls $(C)$ showing the significantly increased proportion of NR2D subunit mRNA in the schizophrenic cohort. The small increase in $C$ is not significant. The lack of change in relative proportions of NR2 subunit mRNA in the parieto-temporal cortex of schizophrenics is shown in $D$ and of controls in $E$.

\section{Relative proportions of mRNA for NR2 subunits in schizophrenia and control brains}

In the prefrontal cortex of controls, the relative proportions of the NR2 subunit mRNA, listed in descending order, were $39 \pm 3 \%$ (NR2B), $37 \pm 5 \%(\mathrm{NR} 2 \mathrm{~A}), 19 \pm 2 \%(\mathrm{NR} 2 \mathrm{D})$, and $3.5 \pm 0.6 \%$ (NR2C) (Fig. 7A,B). In the prefrontal cortex of schizophrenics, the relative proportions of NR2 subunit mRNA were $35 \pm 3 \%$ (NR2B), $33 \pm 3 \%$ (NR2A), $29 \% \pm 3 \%$ (NR2D), and $2.1 \pm 0.5 \%$ (NR2C) (Fig. 7A,B). The differences between the two cohorts were significant (MANOVA: $\mathrm{F}(3,26)=3.18, p=0.03$ ). The $53 \%$ increase in the proportion of NR2D subunit mRNA in the schizophrenic cohort was significant (ANOVA: $\mathrm{F}(1,28)=5.55, p=$ 0.025 ) (Fig. 8) in contrast to the $11-13 \%$ decrease in the proportion of the NR2A and NR2B subunits, which was not $(p=0.35$, $0.47)$.

The $40 \%$ decrease in the proportion of NR2C subunit mRNA in the schizophrenic cohort was significant (ANOVA: $F(1,28)=$ $5.55, p=0.04$ ). Considering that levels of NR2C subunit mRNA in both cohorts are close to the level at which expression is detectable by means of in situ hybridization histochemistry, the quantification and subsequent statistical evaluation of NR2C mRNA levels has to be viewed cautiously. However, the significant shifts in the relative proportions of the four NR2 subunit mRNA, indicated by the MANOVA results shown above, did not change when NR2C was removed from the analysis and 


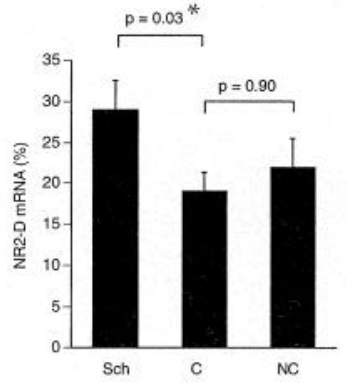

Figure 8. Relative levels of NR2D subunit mRNA (abscissa) in the prefrontal cortex of schizophrenics $(S c h)$, controls $(C)$, and neuroleptictreated controls $(N C)$ (ordinate). Note significant increase (asterisk) in schizophrenics.
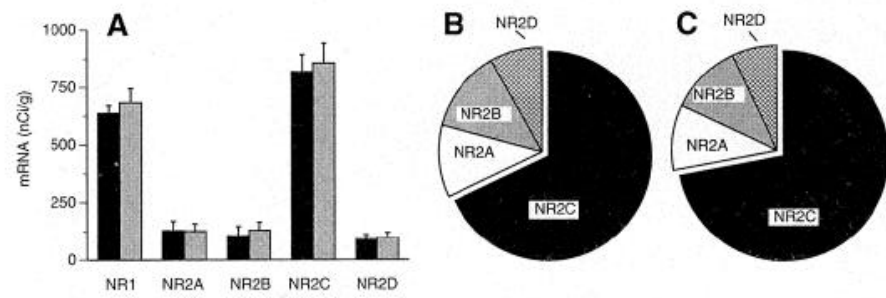

Figure 9. A, Levels of NR1 and NR2A-D subunit-specific mRNA expression in the cerebellar granule cell layer of schizophrenics (black bars) and of controls (shadowed bars). Data are shown as cohort mean \pm SEM. $B$ and $C$, Pie charts of the relative proportions of NR2 mRNAs in the cerebellar granule cell layer of schizophrenics $(B)$ and of controls $(C)$, showing the large proportion of mRNA for NR2C subunit but lack of significant differences between schizophrenics and controls.

MANOVA was performed with NR2A, NR2B, and NR2D only $(p=0.04)$.

In the prefrontal cortex of the neuroleptic-treated control cohort, the relative proportions of the NR2 subunit mRNA, listed in descending order, were $37 \pm 5 \%$ (NR2B), $34 \pm 5 \%$ (NR2A), 23 $\pm 4 \%$ (NR2D), and $4.7 \pm 0.7 \%$ (NR2C). The differences between these and the control cohort were not significant (MANOVA: F $(3,20)=0.13, p=0.94)$. There also were no significant differences in the proportion of individual subunits $(p=0.63-0.94)$. The differences in relative proportions of NR2 subunit mRNA between the neuroleptic-treated control cohort and the schizophrenic cohort were significant (MANOVA: $\mathrm{F}(3,20)=3.39, p=$ 0.04). In the parieto-temporal cortex of controls, the relative proportions of the NR2 subunit mRNA, listed in descending order, were $38 \pm 4 \%$ (NR2B), $34 \pm 4 \%$ (NR2A), $22 \pm 2 \%$ (NR2D), and $5 \pm 1 \%$ (NR2C) (Fig. 7E). In schizophrenics, the relative proportions were $41 \pm 3 \%(\mathrm{NR} 2 \mathrm{~B}), 31 \pm 2 \%(\mathrm{NR} 2 \mathrm{~A})$, $21 \pm 2 \%(\mathrm{NR} 2 \mathrm{D})$, and $4 \pm 1 \%(\mathrm{NR} 2 \mathrm{C})$ (Fig. $7 D)$. The differences did not reach levels of significance (MANOVA: $F(3,26)=1.06$, $p=0.38$ ). The two cohorts also did not differ significantly in the proportions of individual subunits ( $p=0.10-0.74)$.

\section{Quantitative analysis of the mRNA levels in the cerebellar cortex of schizophrenic and control brains}

In the cerebellar cortex of controls, levels of NR1 subunit mRNA were $683 \mathrm{nCi} / \mathrm{gm}$ (Fig. 9A). Levels of NR2C subunit mRNA were $857 \mathrm{nCi} / \mathrm{gm}$. Levels of the other NR2 subunit mRNA were 126 $\mathrm{nCi} / \mathrm{gm} \mathrm{NR} 2 \mathrm{~A}, 129 \mathrm{nCi} / \mathrm{gm} \mathrm{NR} 2 \mathrm{~B}$, and $96 \mathrm{nCi} / \mathrm{gm}$ NR2D (Fig. $9 A)$. In the schizophrenic cohort, levels of NR1 and NR2A-D subunit mRNA differed $<15 \%$ from the control cohort (Fig. $9 A$ ), and no significant differences were observed $(p=0.61-0.93)$. In the control cohort, the relative proportions of NR2 subunit mRNA, listed in descending order, were $69 \pm 4 \%$ (NR2C), $13 \pm$ $2 \%$ (NR2A), $10 \pm 2 \%$ (NR2B), and $6 \pm 1 \%$ (NR2D). The difference between schizophrenics and controls in relative levels of NR2 subunit mRNA was $<15 \%$ for each subunit and without significance $(p=0.78-0.88)$ (Fig. $9 B, C)$.

\section{DISCUSSION}

\section{Diversity of NMDA receptor subunit mRNA expression} in human neocortex

The present study demonstrates that mRNAs for NR1, NR2A, and NR2B subunits of the NMDA receptor are expressed at comparatively high levels in the human neocortex, whereas NR2D subunit mRNA is expressed at intermediate levels and NR2C subunit mRNA only at very low levels. A previous study analyzing the distribution of NR1 subunit immunoreactivity in monkey and human neocortex reported widespread immunostaining in large numbers of pyramidal and other putatively excitatory neurons and in inhibitory, GABAergic neurons of all cortical layers (Huntley et al., 1994). The present study suggests that a similar large majority of cortical neurons coexpresses the NR1 subunit with one, two, or three different NR2 subunit polypeptides, potentially creating heteromeric NMDA receptors with diverse functional properties. This was suggested previously for cerebral cortex of rodents, which until the present study had been the only mammals in which the cortical distribution of mRNA for NMDA receptor subunits had been mapped (Watanabe et al., 1993; Monyer et al., 1994). Neurons in the cerebral cortex of rats and mice express primarily the NR1, NR2A, and NR2B subunits (Watanabe et al., 1993; Monyer et al., 1994). The NR2D subunit is expressed at lower levels only in a subset of cortical neurons, and expression of the NR2C subunit is limited to neuroglial cells scattered throughout cortex and underlying white matter (Watanabe et al., 1993). It seems therefore that differential levels of expression for individual NMDA receptor subunits are similar in rodent and human cerebral cortex. In rodents, however, different functional areas of neocortex seem to have a fairly homogeneous distribution of NMDA receptor subunit mRNA (Watanabe et al., 1993; Monyer et al., 1994) and do not differ substantially in the overall density of binding for various NMDA receptor ligands (Buller et al., 1994). In the human, by contrast, there seems to be a greater level of complexity. A previous receptor-binding study, conducted on human neocortex with ligands binding to the glycine site of the NMDA receptor, reported regional differences. Binding in prefrontal cortex, in particular, was $30-40 \%$ higher compared with parieto-temporal cortex of the supramarginal and angular gyri (Ishimaru et al., 1994, their Table 1). In light of the present findings, which show higher levels of mRNAs for NMDA receptor subunits in prefrontal cortex than in parieto-temporal cortex, it seems that the expression of NMDA receptors in human neocortex is regulated differentially in different functional regions. According to the present study and other in vivo studies (Buller et al., 1994; Farrant et al., 1994; Fitzgerald et al., 1995), the regulation occurs at the level of gene transcription or mRNA turnover; the role of translational regulation (Sucher et al., 1993) and the possibility of changes in relative proportions of NR1 splice variants remain to be explored.

The relatively high mRNA levels and ligand-binding sites for NMDA receptors in the prefrontal cortex imply that NMDA receptors could play an important role in frontal lobe-specific functions (Fuster, 1985), including the establishment of frontal lobe-associated working memory (Goldman-Rakic, 1995). The 
observation that the NMDA receptor channel blocker ketamine potentially disrupts cognitive tasks thought to be mediated by the prefrontal cortex, such as the Wisconsin card sorting test (Bennett et al., 1995), indicates that compromised NMDA receptor function has potentially important consequences for frontal lobe function.

\section{Gene expression for NMDA receptor subunits in human cerebellar cortex}

The very high levels of NR2C subunit mRNA in the granule cell layer of the cerebellar cortex were in sharp contrast to the very low levels of this mRNA in the cerebral cortex. Levels of mRNAs for the NR2A, NR2B, and NR2D subunits, conversely, were very low in the cerebellar cortex, indicating that the expression pattern of genes for the NR2 subunit family is opposite and complementary in human cerebral and cerebellar cortex. This has also been reported in rodents (Kutsuwada et al., 1992; Akazawa et al., 1994; Monyer et al., 1994). Based on the labeling pattern of film autoradiograms, the present study found no evidence for a substantial expression of NR2 subunits in Purkinje cells. Histological studies in the rodent reported either no detectable levels (Monyer et al., 1994) or very low levels of NR2 subunit mRNA (Akazawa et al., 1994) and protein (Petralia et al., 1994a) in the Purkinje cell layer. Considering that functional NMDA receptors are virtually absent in mature Purkinje cells (Dupont et al., 1987; Garthwaite et al., 1987), the very high levels of NR1 subunit mRNA (Akazawa et al., 1994; Monyer et al., 1994) and protein (Brose et al., 1993; Petralia et al., 1994b) in these neurons may indicate that this particular NMDA receptor subunit not only is integrated into NMDA receptor channels but also has additional, yet unknown functions.

\section{Selective alterations in the prefrontal cortex of schizophrenics}

The present study demonstrates that the prefrontal cortex of schizophrenics has abnormal relative proportions of mRNAs for the four different NR2 subunit polypeptides, primarily because of the $53 \%$ increase in relative levels of mRNA for the NR2D polypeptide. It is apparent, however, that brains of schizophrenics do not show a generalized abnormality in the expression pattern of NMDA receptor subunits. The lamina-specific expression and the regional heterogeneity in overall levels of subunit mRNA was preserved in the frontal and parieto-temporal cortex of schizophrenics. In addition, the same complementary distribution of mRNA for the NR2 subunits in the cerebral and cerebellar cortex observed in controls was found in schizophrenics, as was the subunit-specific expression in Purkinje cells. These results make it unlikely that a generalized dysfunction of the NMDA receptor or a fundamental abnormality in the pattern of gene expression for individual receptor subunits is a primary factor in the pathophysiology of schizophrenia.

Lack of comparable changes in the neuroleptic-treated control group indicates that the changes observed in the prefrontal cortex of the schizophrenic cohort of the present study are unlikely to be drug treatment-related effects. This finding is also supported by animal studies demonstrating that the blockade of dopamine (D) receptors by typical neuroleptics such as haloperidol does not alter NMDA receptor gene expression in the cingulate and adjacent prefrontal cortex, but instead selectively changes levels of NR1 mRNA and protein in the striatum (Fitzgerald et al., 1995).

\section{Implications for disordered frontal lobe functions in schizophrenia}

The potential importance of NMDA receptor activity for the normal frontal cortex, as outlined above, implies that NMDA receptors could be involved in conditions that are accompanied by dysfunction and hypoactivity of the frontal lobe, as frequently observed in patients with schizophrenia (Ingvar and Franzen, 1974; Buchsbaum et al., 1984; Weinberger et al., 1986; Andreasen et al., 1992; Tamminga et al., 1992). The question, then, is how the present findings, i.e., upregulation of NR2D mRNA and changes in the relative proportions of NR2 subunit mRNA, might be related to the hypofrontality of schizophrenia.

In rodent cerebral cortex, the expression of the NR2D subunit is developmentally regulated and is most prominent during the first postnatal week (Monyer et al., 1994), when neuronal activity is only moderate (Armstrong-James and Fox, 1988) but nonetheless required to induce the formation of specific neuronal connections, which are mediated in part by NMDA receptors (Kleinschmidt et al., 1987; Schlaggar et al., 1993; Li et al., 1994). Recombination experiments in cell culture demonstrated that NMDA receptors assembled from NR1 and NR2D subunits show a prolonged decay rate of glutamate-induced ion currents and a lowered threshold for voltage-dependent $\mathrm{Mg}^{2+}$ blockade compared with NMDA receptors assembled from NR1 and NR2A or NR2B subunits (Monyer et al., 1994). These special kinetic properties of (presumably) postsynaptic NMDA receptors containing the NR2D polypeptide are thought to ensure effective postsynaptic depolarization under conditions when presynaptic activity is reduced (Monyer et al., 1994), as observed for example at immature synapses in the developing brain (Armstrong-James and Fox, 1988; Hestrin, 1992). Therefore, the increased proportion of this "hyperexcitable" type of NMDA receptor in the prefrontal cortex of adult schizophrenics could be a significant response to prefrontal hypoactivity in order to compensate for a general reduction in neuronal activity and concomitant deficits in afferent input to excitatory, NMDA receptor-containing synapses. Although the primary cause of prefrontal dysfunction in schizophrenia remains to be identificd, it is now cvident that not one but many neurotransmitter systems, including the GABAergic (Benes et al., 1992, 1993; Akbarian et al., 1995), serotoninergic (Arora and Meltzer, 1991; Laruelle et al., 1993), and glutamatergic systems (Deakin et al., 1989) are compromised. This may be brought about by deficits in synaptic proteins (Browning et al., 1993; Glantz and Lewis, 1994) and loss of neuropil (Selemon et al., 1993), as seen in some samples of schizophrenics. Alterations of this kind, on the other hand, are potential indicators of a profound defect in connectivity patterns of the prefrontal cortex, which in some schizophrenics could be attributable to a developmental defect in the formation of corticocortical and thalamocortical connections (Hyde et al., 1992; Akbarian et al., 1993a,b, 1995). Therefore, alterations in gene expression for NMDA receptor subunits, as reported in the present study, and the abnormalities in prefrontal metabolism demonstrated by ketamine challenge in in vivo imaging studies of schizophrenics (Breier et al., 1995) may indicate a disturbance of NMDA receptor-mediated signal transduction that ultimately could be caused by an abnormality in the neural circuitry of the frontal lobe.

\section{REFERENCES}

Akazawa C, Shigemoto R, Bessho Y, Nakanishi S, Mizuno N (1994) Differential expression of five $N$-methyl-D-aspartate receptor mRNA in 
the cerebellum of developing and adult rats. J Comp Neurol $347: 150-160$

Akbarian S, Bunney WE Jr, Potkin SG, Wigal SB, Hagman JO, Sandman CA, Jones EG (1993a) Altered distribution of nicotinamide-adenine dinucleotide phosphate-diaphorase cells in frontal lobe of schizophrenics implies disturbances of cortical development. Arch Gen Psychiatry 50:169-177.

Akbarian S, Viñuela A, Kim JJ, Potkin SG, Bunney WE Jr, Jones EG (1993b) Distorted distribution of nicotinamide-adenine dinucleotide phosphate-diaphorase neurons in temporal lobe of schizophrenics implies anomalous cortical development. Arch Gen Psychiatry 50:178-187.

Akbarian S, Kim JJ, Potkin SG, Hagman JO, Tafazzoli A, Bunney WE Jr, Jones EG (1995) Gene expression for glutamic acid decarboxylase is reduced without loss of neurons in prefrontal cortex of schizophrenics. Arch Gen Psychiatry 52:258-266.

Andreasen NC, Rezai K, Alliger R, Swayze VW II, Flaum M, Kirchner P, Cohen G, O'Leary DS (1992) Hypofrontality in neuroleptic-naive patients and in patients with chronic schizophrenia. Assessment with xenon 133 single-photon emission computed tomography and the Tower of London. Arch Gen Psychiatry 49:943-958.

Armstrong-James M, Fox K (1988) The physiology of developing cortical neurons. In: Cerebral cortex, Vol 7, Development and maturation of cerebral cortex (Peters A, Jones EG, eds), pp 237-272. New York: Plenum.

Arora RC, Meltzer HY (1991) Serotonin S $_{2}\left(5-\mathrm{HT}_{2}\right)$ receptor hinding in the frontal cortex of schizophrenic patients. J Neural Transm 85:19-29.

Benes FM, Snyder-Marie A, Vincent S, Khan Y (1993) Upregulation of $\mathrm{GABA}_{\mathrm{A}}$ receptor binding activity in prefrontal cortex of schizophrenic brain. Soc Neurosci Abstr 23:8.

Benes FM, Vincent SL, Alsterberg G, Bird ED, SanGiovanni JP (1992) Increased $\mathrm{GABA}_{\mathrm{A}}$ receptor binding in superficial layers of cingulate cortex in schizophrenics. J Neurosci 12:924-929.

Bennett A, Abi-Saab D, Karper L, D'Souza DC, Abi-Dargham A, Charney D, Krystal J (1995) Ketamine impairs learning, but not procedural expression, on the Wisconsin card sorting test. Schizophr Res 15:108.

Bockers TM, Zimmer M, Muller A, Bergmann M, Brose N, Kreutz MR (1994) Expression of the NMDA R1 receptor in selected human brain regions. NeuroReport 5:965-969.

Breier A, Malhotra A, Pinals A, Chung I-W, Hidary J, Su T-P, Hsiao J, Pickar D (1995) Neuroanatomical localization of NMDA receptormediated psychosis in healthy controls and schizophrenic patients. Schizophr Res 15:77.

Brodmann K (1909) Vergleichende Lokalisationslehre der Grosshirnrinde auf Grund des Zellenbaues. Leipzig: Barth.

Brose N, Gasic GP, Vetter DE, Sullivan JM, Heinemann SF (1993) Protein chemical characterization and immunocytochemical localization of the NMDA receptor subunit NMDA R1. J Biol Chem 268:22663-22671.

Browning MD, Dudek EM, Rapier JL, Leonard S, Freedman R (1993) Significant reductions in synapsin but not synaptophysin specific activity in the brains of some schizophrenics. Biol Psychiatry 34:529-535.

Buchsbaum MS, DeLisi LE, Holcomb HH, Cappelletti J, King AC, Johnson J, Hazlett E, Dowling-Zimmerman S, Post RM, Morihisa J, Carpenter W, Cohen R, Pickar D, Weinberger DR, Margolin R, Kessler RM (1984) Anteroposterior gradients in cerebral glucose use in schizophrenia and affective disorder. Arch Gen Psychiatry 41:1159-1166.

Buller AL, Larson HC, Schneider BE, Beaton JA, Morrisett RA, Monaghan DT (1994) The molecular basis of NMDA receptor subtypes: native receptor diversity is predicted by subunit composition. J Neurosci 14:5471-5484.

Bunney BG, Bunney WE Jr, Carlsson A (1995) Schizophrenia and glutamate. In: Psychopharmacology: the fourth generation of progress (Bloom FE, Kupfer DJ, eds), pp 1205-1214. New York: Raven.

Carlsson M, Carlsson A (1990) Schizophrenia: a subcortical neurotransmitter imbalance syndrome. Schizophr Bull 16:425-432.

Deakin JFW, Simpson MDC, Gilchrist AC, Skan WJ, Royston MC, Reynolds GP, Cross AJ (1989) Frontal cortical and left temporal glutamatergic dysfunction in schizophrenia. J Neurochem 52:1781-1786.

Dupont J-L, Gardette R, Crepel F (1987) Postnatal development of the chemosensitivity of rat cerebellar Purkinje cells to excitatory amino acids. An in vitro study. Dev Brain Res 34:59-68.
Farrant M, Feldmeyer D, Takahashi T, Cull-Candy SG (1994) NMDAreceptor channel diversity in the developing cerebellum. Nature $368: 335-339$

Fitzgerald LW, Deutch AY, Gasic G, Heinemann SF, Nestler EJ (1995) Regulation of cortical and subcortical glutamate receptor subunit expression by antipsychotic drugs. J Neurosci 15:2453-2461.

Fuster JM (1985) The prefrontal cortex and temporal integration. In: Cerebral cortex, Vol 4, Association and auditory cortices (Peters A Jones EG, eds), pp 1-61. New York: Plenum.

Garthwaite G, Yamini B Jr, Garthwaite J (1987) Selective loss of Purkinje and granule cell responsiveness to $N$-methyl-D-aspartate in rat cerebellum during development. Dev Brain Res 36:288-292.

Glantz LA, Lewis DA (1994) Decreased synaptophysin immunoreactivity in prefrontal cortex of schizophrenics. Biol Psychiatry 35:717.

Goldman-Rakic PS (1995) Cellular basis of working memory. Neuron $14: 477-485$.

Hestrin S (1992) Developmental regulation of NMDA receptor-mediated synaptic currents at a central synapse. Nature 357:686-689.

Hollmann M, Heinemann S (1994) Cloned glutamate receptors. Annu Rev Neurosci 17:31-108.

Huntley GW, Vickers JC, Janssen W, Brose N, Heinemann SF, Morrison JH (1994) Distribution and synaptic localization of immunocytochemically identified NMDA receptor subunit proteins in sensory-motor and visual cortices of monkey and human. J Neurosci 14:3603-3619.

Hyde TM, Ziegler JC, Weinberger DR (1992) Psychiatric disturbances in metachromatic leukodystrophy: insights into the neurobiology of psychosis. Arch Ncurol 49:401-406.

Ingvar DH, Franzen G (1974) Abnormalities of cerebral blood flow distribution in patients with chronic schizophrenia. Acta Psychiatr Scand $50: 425-462$

Ishii T, Moriyoshi K, Sugihara H, Sakurada K, Kadotani H, Yokoi C, Akazawa R, Shigemoto R, Mizuno N, Nakinishi S (1993) Molecular characterization of the family of the $\mathrm{N}$-methyl-D-aspartate receptor subunits. J Biol Chem 268:2836-2843.

Ishimaru M, Kurumaji A, Toru M (1994) Increases in strychnine-insensitive glycine binding sites in cerebral cortex of chronic schizophrenics: evidence for glutamate hypothesis. Biol Psychiatry 35:84-95.

Javitt DC, Zukin SR (1991) Recent advances in the phencyclidine model of schizophrenia. Am J Psychiatry 148:1301-1308.

Javitt DC, Zylberman I, Zukin SR, Heresco-Levy U, Lindenmayer J-P (1994) Amelioration of negative symptoms in schizophrenia by glycine. Am J Psychiatry 151:1234-1236.

Johnson AW, Ascher P (1987) Glycine potentiates the NMDA response in cultured mouse brain neurons. Nature 325:529-531.

Jones EG, Hendry SHC, Liu XB, Potkin SG, Tourtellotte WW (1992) A method for fixation of previously fresh frozen human adult and fetal brains that preserves histological quality and immunoreactivity. J Neurosci Methods 44:133-144.

Kerwin R, Patel S, Meldrum B (1990) Quantitative autoradiographic analysis of glutamate binding sites in the hippocampal formation in normal and schizophrenic brain post mortem. Neuroscience 39:25-32.

Kleinschmidt A, Bear MF, Singer W (1987) Blockade of NMDA receptors disrupts experience-dependent modifications in kitten striate cortex. Science 238:355-358.

Kohr G, Eckardt S, Luddens H, Monyer H, Seeburg PH (1994) NMDA receptor channels: subunit-specific potentiation by reducing agents. Neuron 12:1031-1040.

Kornhuber J, Mack-Burkhardt F, Riederer P, Hebenstreit GF, Reynolds GP, Andrews HB, Beckmann H (1989) $\left[{ }^{3} \mathrm{H}\right] \mathrm{MK}-801$ binding sites in postmortem brain regions of schizophrenic patients. J Neural Transm 77:231-236

Krystal JH, Karger LP, Seibyl JP, Freeman G, Delaney R, Bremner JD, Heninger GR, Bowers MB, Charney DS (1994) Subanesthetic effects of the noncompetitive NMDA antagonist, ketamine, in humans: psychotomimetic, perceptual, cognitive, and neuroendocrine responses. Arch Gen Psychiatry 51:199-214.

Kumar KN, Tilakaratne N, Johnson PS, Allen AE, Michaelis EK (1991) Cloning of a cDNA for the glutamate-binding subunit of an NMDA receptor. Nature 354:70-73.

Kutsuwada T, Kashiwabuchi N, Mori H, Sakimura K, Kushiya E, Araki K, Meguro H, Masaki H, Kumanishi T, Arakawa M, Mishina M (1992) Molecular diversity of the NMDA receptor channel. Nature 358:36-41.

Laruelle M, Abi-Dargham A, Casanova MF, Toti R, Weinberger DR, Kleinman JE (1993) Selective abnormalities of prefrontal serotonergic receptors in schizophrenia. Arch Gen Psychiatry 50:810-818. 
Le Bourdelles B, Wafford KA, Kemp JA, Marshall G, Bain C, Wilcox AS, Sikela JM, Whiting PJ (1994) Cloning, functional coexpression, and pharmacological characterization of human cDNAs encoding NMDA receptor NR1 and NR2A subunits. J Neurochem 62:2091-2098.

Li Y, Erzurumlu RS, Chen C, Jhaveri S, Tonegawa S (1994) Whiskerrelated neuronal patterns fail to develop in the trigeminal brainstem nuclei of NMDAR1 knockout mice. Cell 76:427-437.

Luby ED, Cohen BD, Rosenbaum G, Gottlieb JS-R (1959) Study of a new schizophrenomimetic drug-Sernyl. Arch Neurol Psychiatry 119:61-65.

Monyer H, Burnashev N, Laurie DJ, Sakmann B, Seeburg PH (1994) Developmental and regional expression in the rat brain and functional properties of four NMI)A receptors. Neuron 12:529-540.

Monyer H, Sprengel R, Schoepfer A, Herb A, Higuchi M, Lomeli H, Burnashev N, Sakmann B, Seeburg PH (1992) Heteromeric NMDA receptors: molecular and functional distribution of subtypes. Science 256:1217-1221.

Olney JW (1989) Excitatory amino acid and neuropsychiatric disorders. Biol Psychiatry 26:505-525.

Petralia RS, Wang Y-X, Wenthold RJ (1994a) The NMDA receptor subunits, NR2A and NR2B, show histological and ultrastructural localization patterns similar to those of NR1. J Neurosci 14:6102-6120.

Petralia RS, Yokotani N, Wenthold RJ (1994b) Light and electron microscope distribution of the NMDA receptor subunit NMDAR1 in the rat nervous system using a selective anti-peptide antibody. J Neurosci 14:667-696.

Potkin SG, Costa J, Roy S, Sramek J, Jin Y, Gulasekaram B (1992) Glycine in the treatment of schizophrenia: theory and preliminary results. In: Novel antipsychotic drugs (Meltzer HY, ed), pp 179-188. New York: Raven.

Preuss TM, Goldman-Rakic PS (1991) Myelo- and cytoarchitecture of the granular frontal cortex and surrounding regions in the strepsirhine primate Galago and the anthropoid primate Macaca. J Comp Neurol 310:429-474

Rosse RB, Theut SK, Banay-Schwartz M, Leighton M, Scarcella E, Cohen CG, Deutsch SI (1989) Glycine adjuvant therapy to conventional neuroleptic treatment in schizophrenia: an open-label, pilot study. Clin Neuropharmacol 12:416-424.

Schlaggar BL, Fox K, O'Leary DDM (1993) Postsynaptic control of plasticity in developing somatosensory cortex. Nature 364:623-626.
Selemon LD, Rajkowska G, Goldman-Rakic PS (1993) Cytologic abnormalities in area 9 of the schizophrenic cortex. Soc Neurosci $\mathrm{Abstr}$ 19:200.

Simpson MD, Slater P, Royston MC, Deakin JF (1991) Alterations in phencyclidine and sigma binding sites in schizophrenic brains. Effects of disease process and neuroleptic medication. Schizophr Res 6:41-48.

Sucher NJ, Brose N, Deitcher DL, Awobuluyi M, Gasic GP, Bading H, Cepko CL, Greenberg ME, Jahn R, Heinemann SF, Lipton SA (1993) Expression of endogenous NMDAR1 transcripts without receptor protein suggests post-transcriptional control in PC12 cells. J Biol Chem 268:22299-22304.

Sugihara H, Moriyoshi K, Ishii T, Masu M, Nakanishi S (1992) Structures and properties of seven isoforms of the NMDA receptor generated by alternative splicing. Biochem Biophys Res Commun 185:826-832.

Sullivan JM, Traynelis SF, Chen HSV, Escobar W, Heinemann SF, Lipton SA (1994) Identification of two cysteine residues that are required for redox modulation of the NMDA subtype of glutamate receptor. Neuron 13:929-936

Tamminga CA, Thaker GK, Buchanan R, Kirkpatrick B, Alphs LD, Chase TN, Carpenter WT (1992) Limbic system abnormalities identified in schizophrenia using positron emission tomography with fluorodeoxyglucose and neocortical alterations with deficit syndrome. Arch Gen Psychiatry 49:522-530.

Tatsuoka M (1988) Multivariate analysis of variance: technique for educational and psychological research, 2nd ed. New York: MacMillan.

Ulas J, Cotman CW (1993) Excitatory amino acid receptors in schizophrenia. Schizophr Bull 19:105-117.

Watanabe M, Inoue Y, Sakimura K, Mishina M (1993) Distinct distributions of five $N$-methyl-D-aspartate receptor channel subunit mRNA in the forebrain. J Comp Neurol 338:377-390.

Waziri R (1988) Glycine therapy of schizophrenia. Biol Psychiatry 23:210-211.

Weinberger DR, Berman KF, Zec RF (1986) Physiologic dysfunction of dorsolateral prefrontal cortex in schizophrenia. I. Regional cerebral blood flow evidence. Arch Gen Psychiatry 43:114-125.

Zec RF, Weinberger DR (1986) Brain areas implicated in schizophrenia: a selective overview. In: The handbook of schizophrenia, Vol 1, The neurology of schizophrenia (Nasrallah HA, Weinberger DR, eds), pp 175-206. Amsterdam: Elsevier Science. 